\title{
Áttérés a Primo New User Interface használatára a Magyar Tudományos Akadémia Könyvtár és Információs Központban
}

\author{
Haász Antal \\ Magyar Tudományos Akadémia Könyvtár és Információs Központ \\ Szakinformatikai Osztály \\ haasz.antal@konyvtar.mta.hu
}

After the almost one year test-period, we have started to use the Primo NEW UI at the beginning of this year. The NEW UI is based on the modern web technologies. The study is about the main steps of migration: customizing of the opening page, and operational changes to the new library services.

Keywords: Primo, discovery system, web technology, API

\section{Bevezetés}

A Primo New UI bevezetésére - mintegy egy éves előkészitő fázis után - 2019 februárjában került sor az MTA KIK-ben.

A Primo használata nem volt előzmény nélküli könyvtárunkban, hiszen annak "classic" felülete már 2015 novembere óta elérhető volt felhasználóink számára. A rendszer általános jellemzőiröl illetve a 2015-ös bevezetés tanulságairól már egy korábbi tanulmányban beszámoltunk, ${ }^{1}$ ezért ezekröl itt most nem szólunk.

A továbbiakban részletesen ismertetjük az új verzióra (New UI) történő átállás meghatározó pontjait. Bemutatjuk a nyitóoldal - modern webes technológiákon alapuló - egyedi konfigurálásának föbb lépéseit, valamint azokat a müködéssel kapcsolatos fejlesztéseket, amelyekkel a hatékonyabb rendszerhasználatot igyekeztünk elősegíteni.

\section{A nyitóoldal kialakítása}

A munka kezdetekor az Ex Libris által biztositott, standard, minimális szerkezetiés dizájn- elemeket tartalmazó nyitóoldal állt rendelkezésünkre. A kitüzött cél az volt, hogy ezt a kezdetleges és „semleges” felületet egy egyedi, az intézményre jellemző szín- és formavilággal, valamint a felhasználói igényeket eredményesen kiszolgáló, dinamikusan müködő szolgáltatásokkal töltsük meg.

A munka elsősorban a szakinformatikusok és - a felhasználói szokásokat és igényeket leginkább ismerő - olvasószolgálati munkatársak együttmüködésében folyt. Folyamatos volt az egyeztetés a két osztály munkatársai között: ötletbörzék,

$1 \quad H a a ́ s z$, Antal. 2017. "A Primo használata a Magyar Tudományos Akadémia Könyvtár és Információs Központban." In Hagyományok és kihivások V. Múlt és Jövö, 167-178. doi: https://doi.org/10.21862/HagyKihiv_2016.167 
látványtervek elkészitése és véleményezése, hibalisták összeállitása, majd azok alapján történő javitások jellemezték ezt az időszakot.

A nyitóoldal konfigurálására a Primo Back Office felületén elérhetö Customization Manager ad lehetőséget.

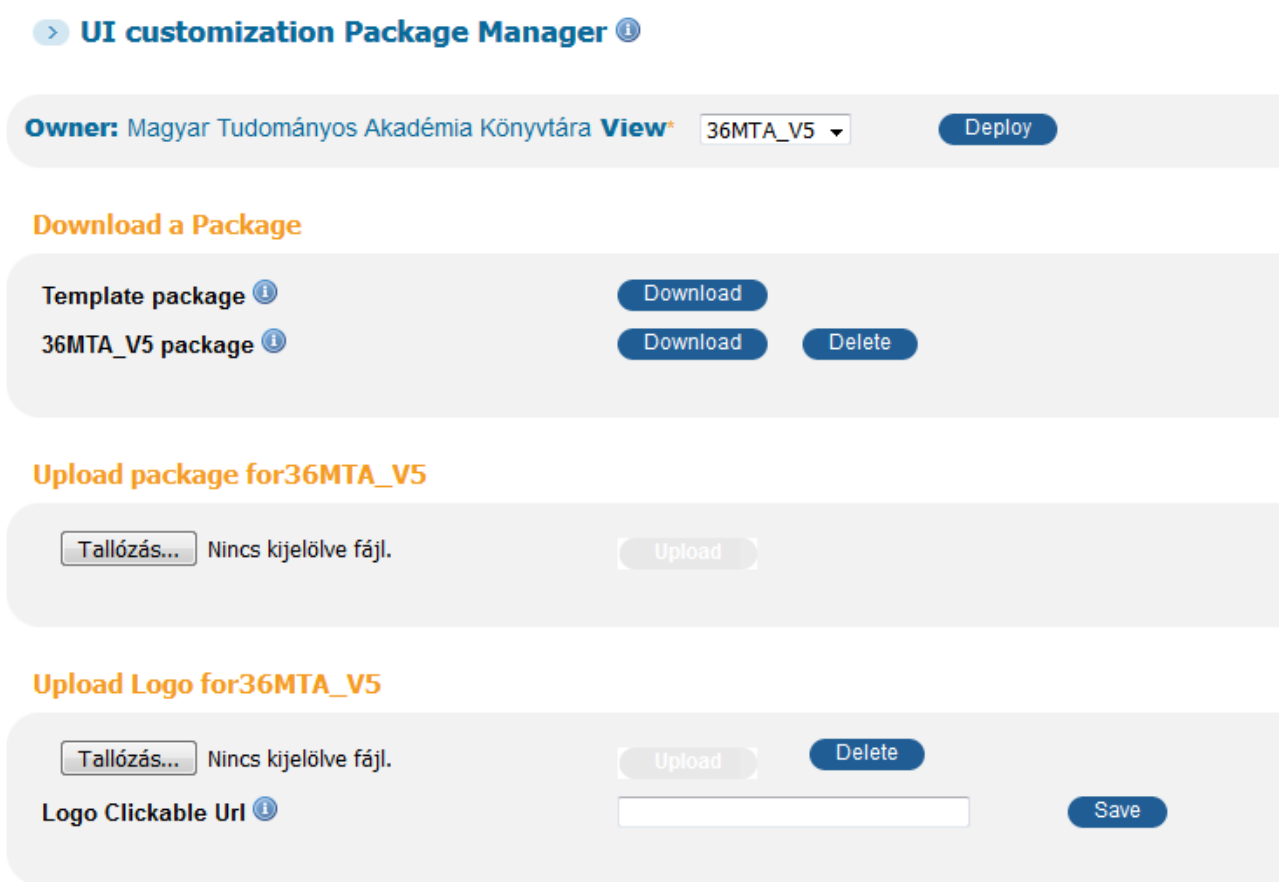

1. ábra A Customization Manager a Primo Back Office-ban

A Customization Manager-rel lehet az egyedi szerkesztéshez szükséges konfigurációs fájlokat és stiluslapokat letölteni, illetve a módositás után azokat visszatölteni. Az úgynevezett Customization Package négy mappát tartalmaz. A HTML mappában érhetőek el nyelvenként a törzsoldal szerkezeti elemei (pl.: home_hu_HU.html), a CSS mappában található custom1.css fájl használatával lehet az egyedi szín- és formavilágot kialakítani. Az IMG mappába szükséges feltölteni a nyitóoldalon, illetve keresési felületeken használni kivánt képi elemeket (pl. librarylogo.png), továbbá a JS mappában található custom.js fájlban lehet JavaScript kódokat rögziteni bonyolultabb webes megoldások alkalmazására.

Elsőként az egyedi fejléc kialakitásához fogtunk hozzá.

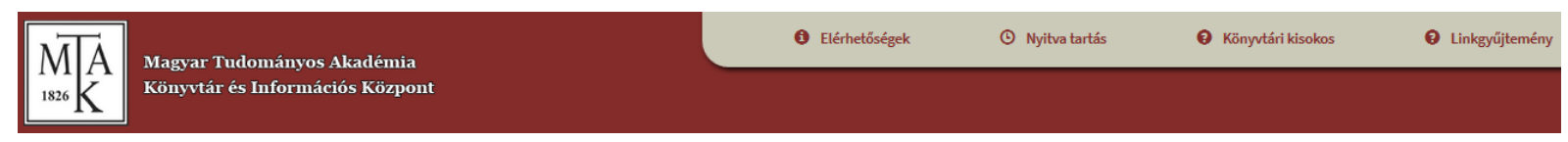

2. ábra A Primo egyedi fejléce az MTA KIK-ben 


\section{Haász Antal: Áttérés a Primo New User Interface használatára a Magyar Tudományos Akadémia Könyvtár és Információs Központban}

A munkát megkönnyitette, hogy a GitHub-on egy számunkra megfelelő menüszerkezetet leíró alap-kódkészlet volt elérhetö. ${ }^{2}$

A letöltött kód-részletet a custom.js fájlban kellett beilleszteni. Ugyanitt kellett létrehozni - html-kódolással - a megjelenitendö menüpontokat is. A könyvtári logo feltöltésével (IMG mappa) majd a könyvtári honlappal korreláló szinvilág kialakitásával (custom1.css) véglegesitettük az új verzió egyedi fejlécét.

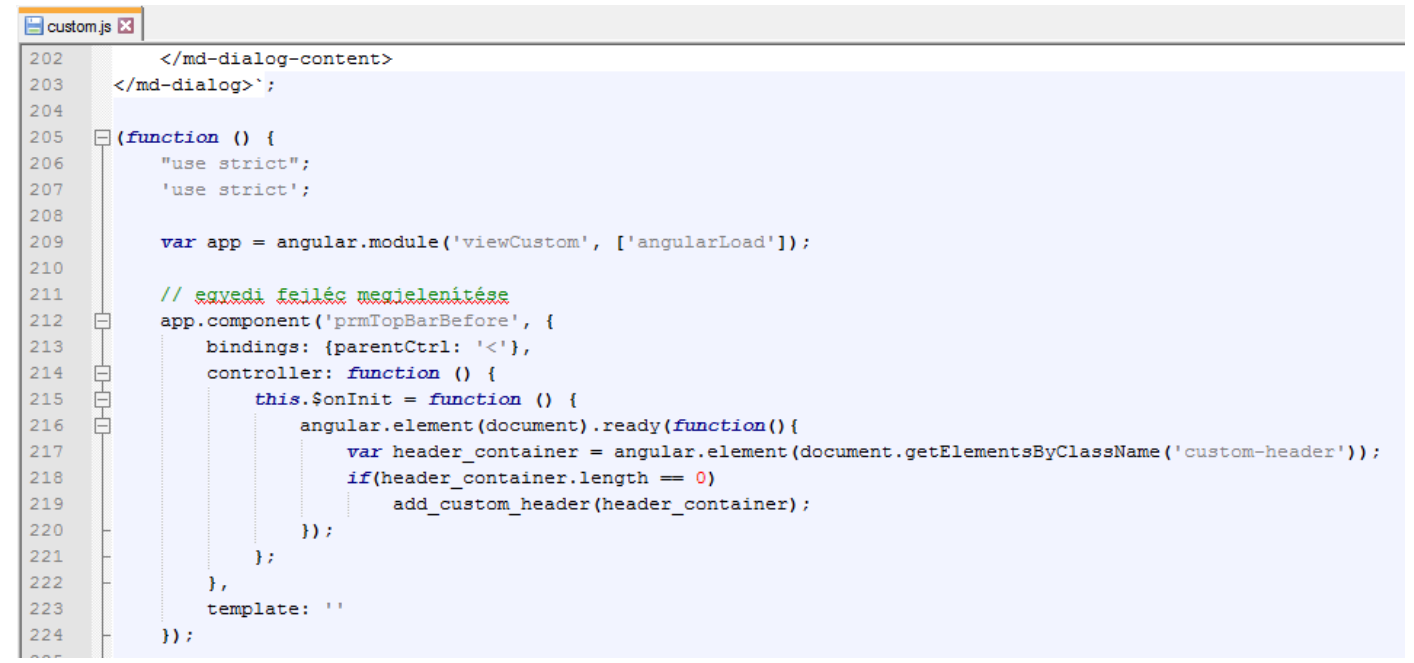

3. ábra A GitHub-ról letötltött kódrészlet a custom.js fájlban

Fontos szerepet szántunk az oldalon a hírblokknak, hiszen felhasználóink ezen keresztül tájékozódhatnak a könyvtárral kapcsolatos aktualitásokról. ${ }^{3}$

A „classic” felületre éveken keresztül "manuálisan”, egyenként megszerkesztve tettük fel a híreket. Ennek kiváltására kerestünk egy olyan új módszert, amely a meglévö hírforrások (könyvtári honlap, könyvtári hírlevél) alapján automatikus hírmegjelenést eredményez. A lehetöségek áttekintése után a megoldást a Primo és a könyvtári hírlevél (WordPress) közötti RESTful API-n alapuló kommunikációban találtuk meg. A müködés alapfeltétele volt, hogy a WordPress oldalon telepitve és engedélyezve legyen a REST API. A WordPress oldal kezelöjének továbbá feladata, hogy a Primo-n is megjeleniteni kivánt hírt egy meghatározott kategóriába (Primo) sorolja. A müködés során a Primo-ból egy úgynevezett HTTP GET kérés indul a Hírlevél felé, amely úgy van megírva, hogy az utolsó három, Primo-kategóriába sorolt hirt vegye át, majd jelenitse meg a kezdőoldal hir szekciójában. Mindezek eredményeképpen a Primo-ban folyamatos az automatikus hirátvétel a könyvtár hírleveléböl.

\footnotetext{
2 Hozzáférés: 2019.06.24., https://aithub.com/pdxlibrary/Custom-Header-for-Primo-Explore-Primo-NUI-

3 Mivel a könyvtári honlapon (https://konyvtar.mta.hu/) is folyamatos a könyvtárral kapcsolatos hiradás, ezért megegyezés született arról, hogy a Primo-n elsősorban a katalógussal, az új könyvtári beszerzésekkel, adatbázisokkal kapcsolatos híreket szerepeltetjük, illetve csak a fontosabb nyitva tartási (pl. nyári szünet) információkat közöljük.
} 


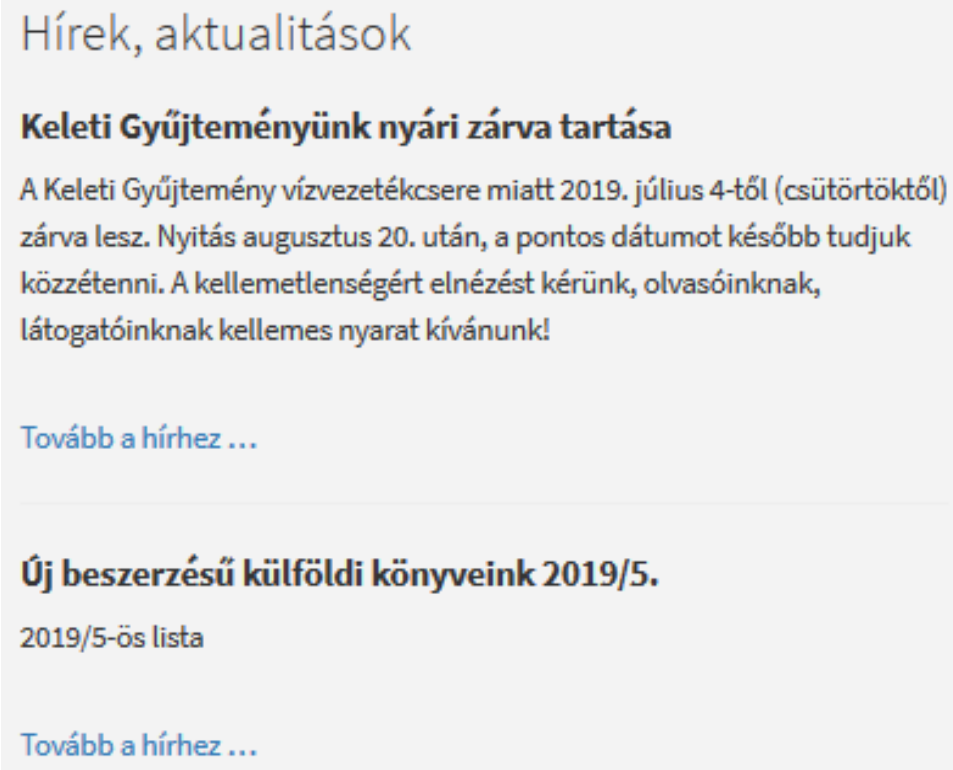

4. ábra Hírmegjelenítés a Primo-n

Könyvtárunkban folyóiratokra és különgyüjteményi dokumentumokra elökészitési igényeket lehet leadni. Igyekeztünk az igénylés folyamatát minél inkább leegyszerüsiteni. Ennek érdekében könnyen kezelhető ürlapokat terveztünk, amelyek révén olvasóink már a nyitóoldalról intézhetik lefoglalási kéréseiket.

Az ürlap kitöltése és elküldése után, a Primo HTTP POST kérést küld egy másik URL-re (work.mta.hu) JSON formátumban. A megszólitott szerveren a kérés hatására lefutnak a megfelelő php-scriptek, amelyek feldolgozzák a beérkező adatokat és e-mail értesítéseket küldenek ki egyrészt az olvasószolgálati munkatársaknak az új kérésről, másrészt a felhasználónak arról, hogy a kérés teljesitése folyamatban van.

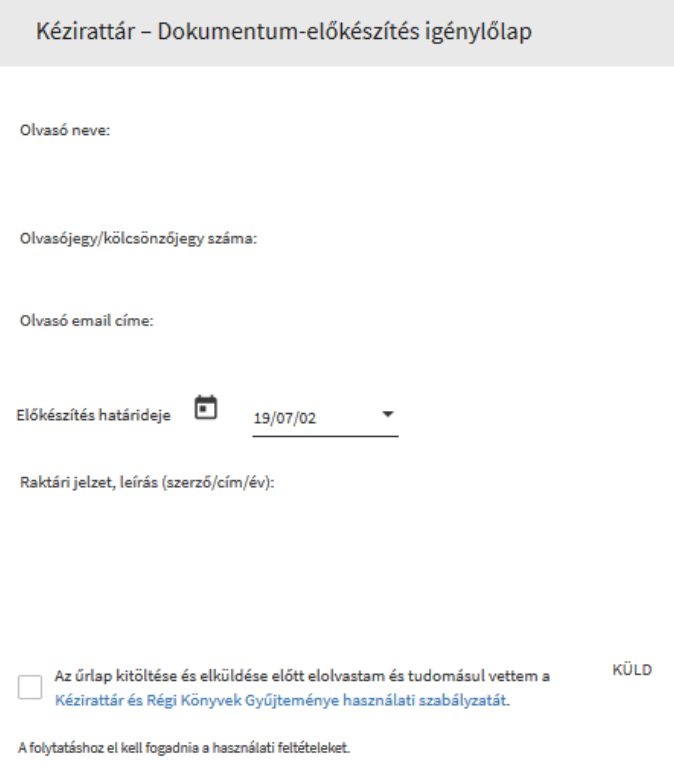


A fent bemutatott fejlesztések eredményeképpen megszületett a nyitóoldal azon verziója, ami most is - néhány kisebb módositással - használatban van.

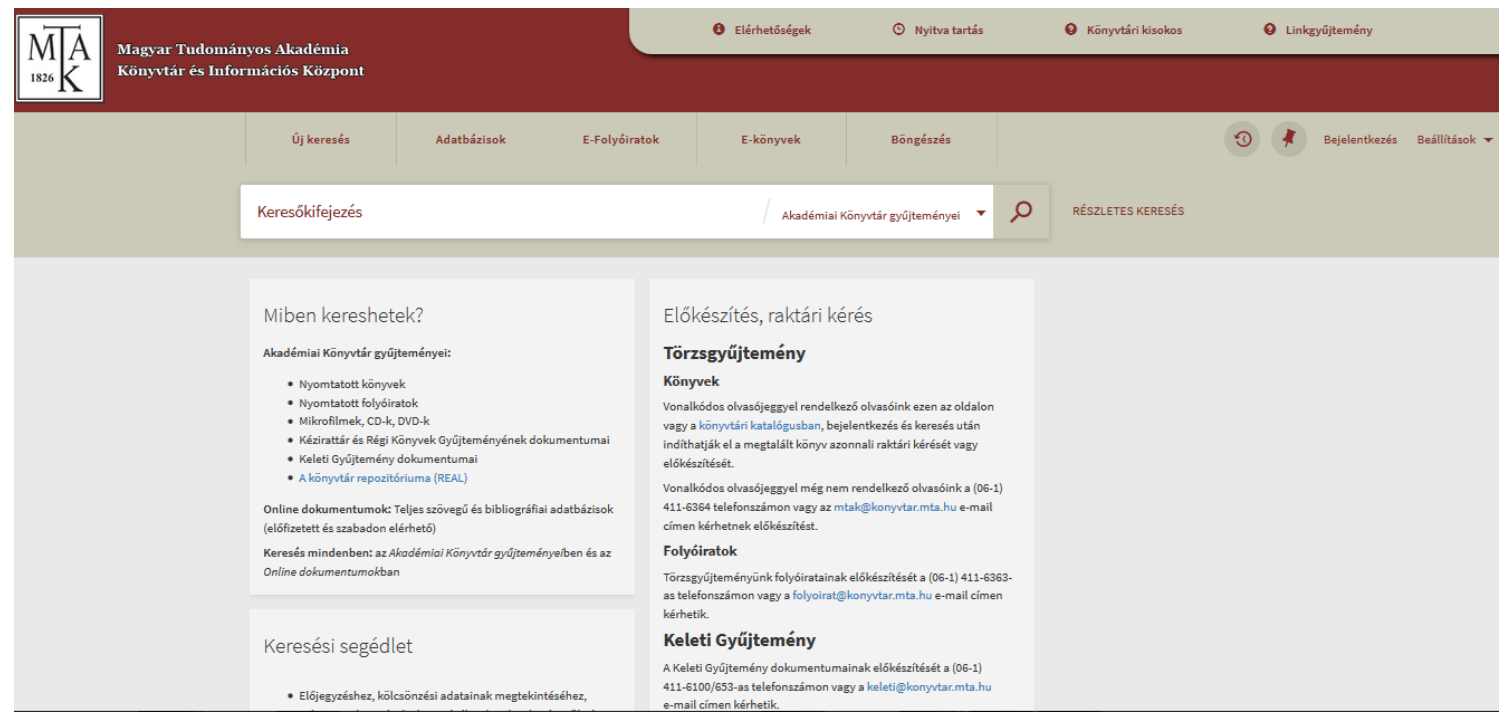

6. ábra Részlet a Primo nyitóoldalából

\section{A keresés és az adatmegjelenítés fejlesztése}

A Primo - mint a discovery rendszerek általában - lehetövé teszi a könyvtár teljes (hagyományos, elektronikus, illetve digitális) gyüjteményének egyidejü lekeresését. Az egyszerü (egymezős) keresés mellett lehetöségünk van részletes keresési adatok megadására, valamint böngészésre is. Kereshetünk csak valamely rész adatbázisban (scope) ${ }^{4}$ vagy választhatjuk az összes gyüjteményben való keresést.

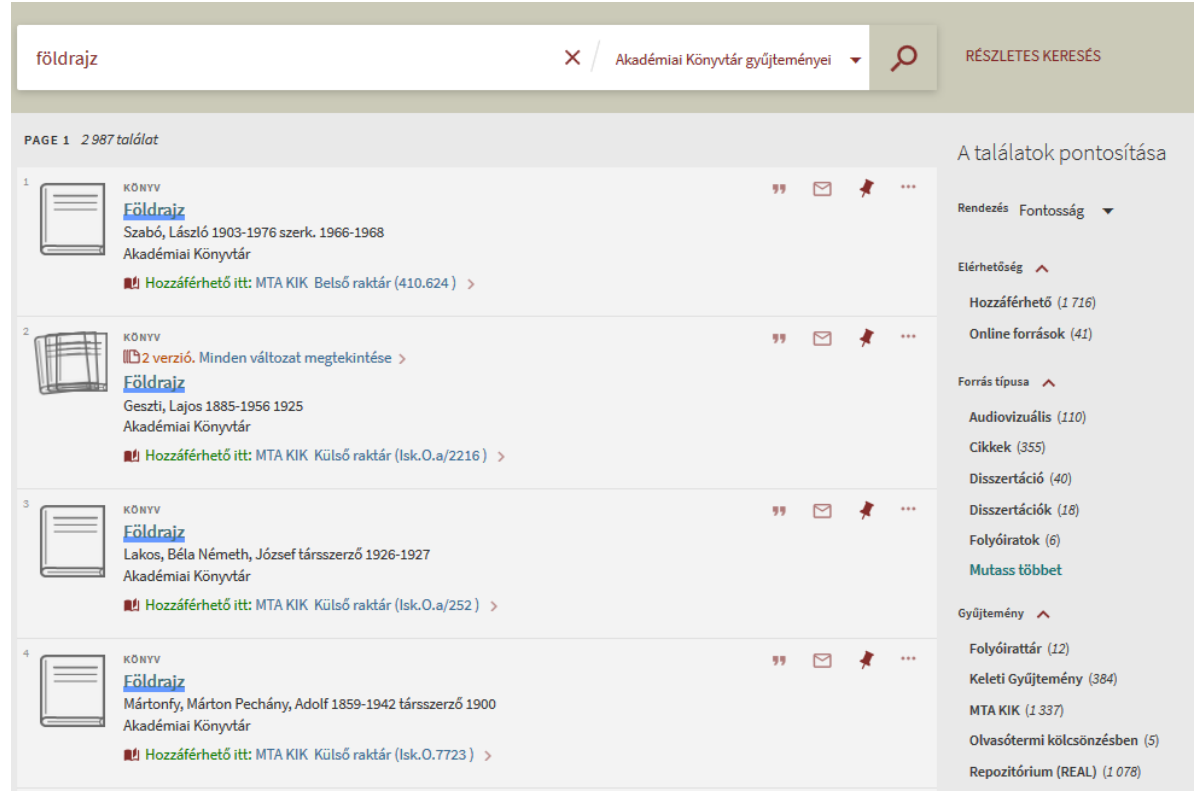

7. ábra A kereső oldal, a találati halmaz és a facetták a Primo-ban

4 Az MTA KIK Primo-jában két keresöcsoportot hoztunk létre: az Akadémiai Könyvtár gyüjteményei (ebben benne vannak a repozitóriumi dokumentumok is), valamint az Online dokumentumok csoportokat. 
A keresés lefolytatása után a Primo úgynevezett facetták alkalmazásával a találatokat rendezi, csoportosítja, ami - különösen a nagyszámú találati lista esetén - jelentősen növelheti a keresés hatékonyságát.

Tapasztalataink alapján a felhasználóink számára fontos szempont a dokumentum típusa alapján történő szükitési lehetőség. Ezért a New UI elinditásakor egy új, a dokumentum típusára utaló facetta bevezetését határoztuk el, amelyet "Forrás típusa" megjelöléssel használunk.

Könyvtári integrált rendszerünkben $(A L E P H)^{5} 2017$ márciusában tértünk át egy új dokumentumtipológia ${ }^{6}$ használatára. Az addig használt 7 formátum mellett, azok differenciált bontásával további 23 formátumot kezdtünk el használni.

Az új facetta müködését az átdolgozott dokumentumtipológia alapján kivántuk felépiteni.

Aleph-ben alapértelmezetten az FMT-mezöben jelenik meg egy adott bibliográfiairekord vonatkozásában a típus-információ. Emellett a rendszer lehetőséget kinál arra is, hogy ugyanezt az információt egy másik, úgynevezett TYP virtuális mezöben is tároljuk. A TYP mező a rekordok LDR, illetve 008-as mezőinek értéke alapján épül fel. ${ }^{7}$

A TYP-mező a rendszer-beállitások alapján az Aleph-rekordok publikálásakor átkerül a Primo-ba, így az MARC21/PNX8 mezömegfeleltetés alapjává tehető.

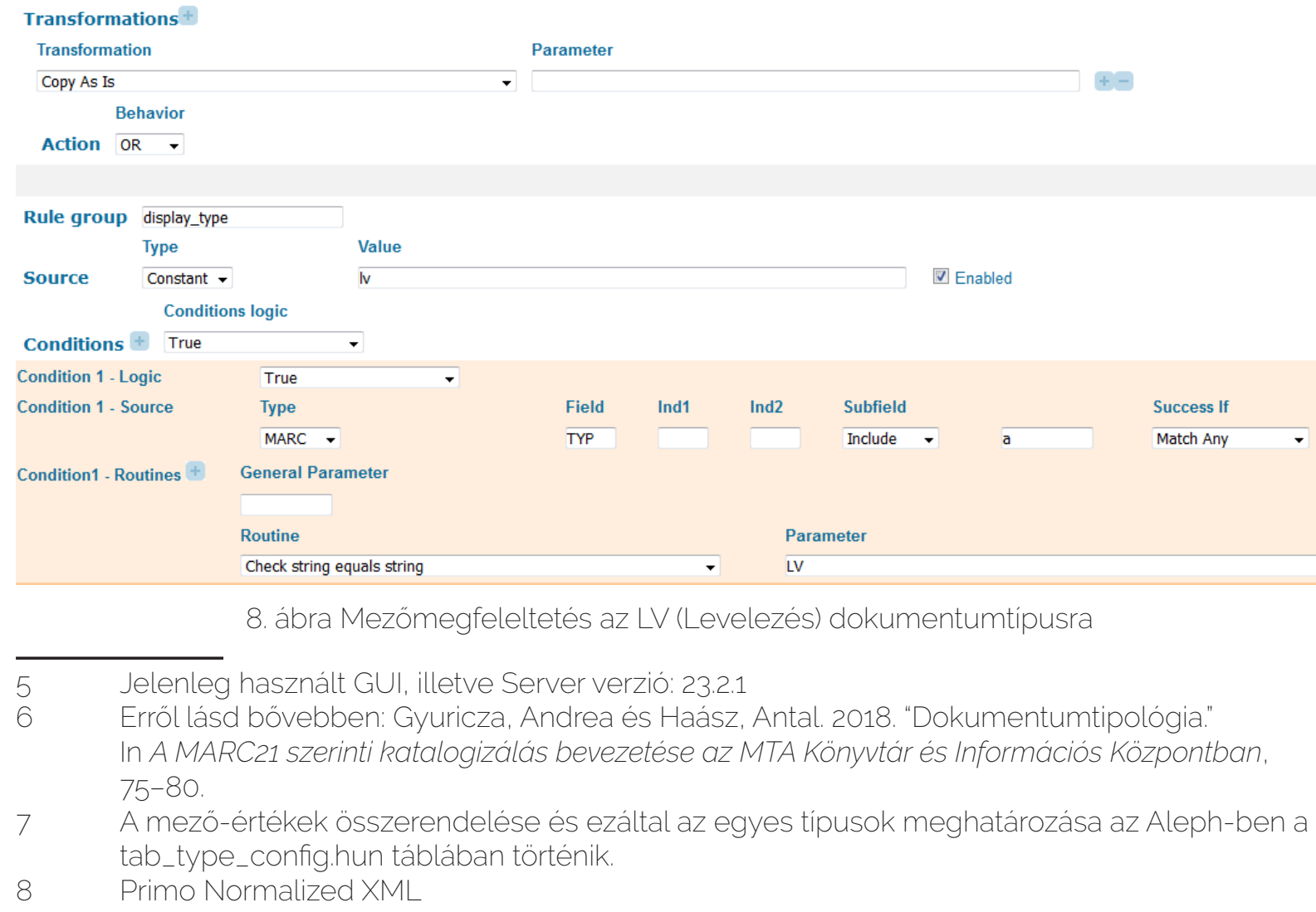


Minden típushoz ikon is rendelhetö, amely a szöveges megjelölés mellett vizuálisan is megjeleníti az adott tétel formátumát.

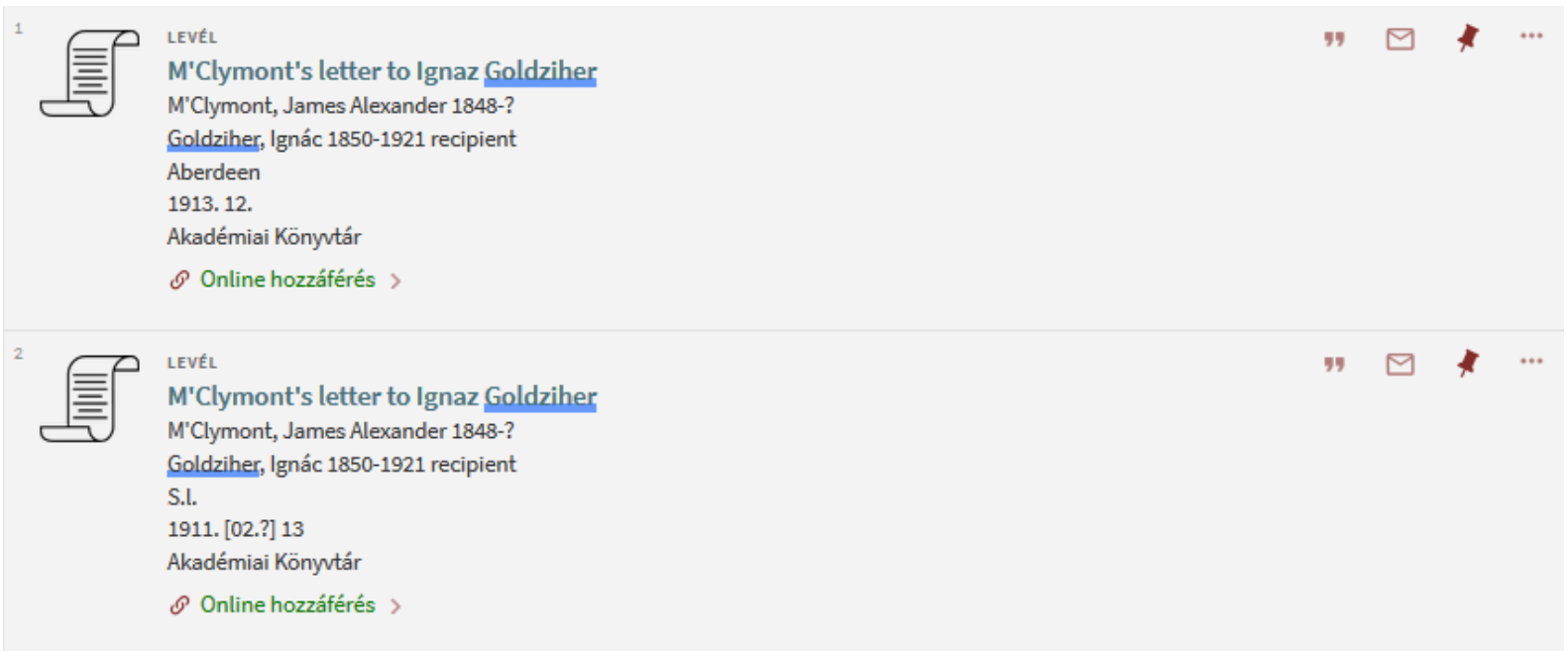

9. ábra Dokumentumtípus-megjelenités a Primo-ban

A leggyakrabban használt típusokra már elvégeztük a megfeleltetéseket, igy azok már láthatóak a Primo-ban. Terveink szerint a teljes dokumentumtipológia átültetésre fog kerülni a Primo-ban.

Azadatmegjelenités kapcsán mind a rövid, minda részletes nézetben módositásokat hajtottunk végre.

A találati listában zavaróan egymásra torlódtak a mü adatai, megnehezítve az áttekintést. A probléma megoldása érdekében minden adatcsoportot külön sorba helyeztünk, amit úgy értünk el, hogy Back Office vonatkozó részében mezőhatárolónak (delimiter) a <br> html-tag-et vettük fel.

A Részletek fülön jó néhány, tájékoztatási szempontból fontos adattartalom nem volt elérhető. Ezért - konzultálva az olvasószolgálatos és feldolgozó kollégákkal megkezdtük ezen adatok pótlását a felületen, amelyet szintén a már fent emlitett mezőmegfeleltetéssel végeztünk. A munka során megjegyzés (például 500, 502, $506,535,540)$, illetve folyóiratok állományadatait megjelenitő mezőket $(876,877)$ tettünk láthatóvá itt.

Az adatmegjelenités konfigurálása nem lezárt folyamat. Az igényeknek megfelelően bármikor vehetünk ki-, illetve tehetünk be adatcsoportot a felhasználói felületekre.

\section{Raktári kérés a Primo-ban}

A Primo-ban az elöjegyzés funkció használatával valósitottuk meg az online raktári kérés lehetőségét. A klasszikus értelemben vett előjegyzési funkció9

9 Kölcsönzésben lévő dokumentumra - általában külön dij ellenében - leadható foglalás. A dokumentum visszaérkezéséröl a könyvtár értesiti a foglalást kezdeményező olvasót és megadott ideig félreteszi számára a kért dokumentumot. 
használata könyvtári gyakorlatunkban nincs (és nem is volt) jelen (csak raktárban lévő dokumentumra lehet elöjegyzést tenni, kölcsönzésben lévőre nem). Ezért esetünkben helyesebb inkább előkészitési vagy lefoglalási rendszerröl beszélni. Ennek megfelelően kellett a Primo-ban is kialakitani az előjegyzési rendszert, módositva az eredeti beállitásokat.

A kölcsönzésben lévő dokumentumok elöjegyzésének blokkolását Aleph beállitásokkal tudtuk megoldani a Primo-ban is. ${ }^{10}$ Egy paraméter-tábla egyik ellenőrzési procedúrájával ${ }^{11}$ - a megjelölt olvasói státuszok esetében - a kölcsönzéseket tartós kölcsönzéssé lehet minösiteni, amelyekre nem lehet elöjegyzést tenni. Ebben a táblában az összes olvasói státuszt felsoroltuk, így gyakorlatilag - a célnak megfelelöen - az összes kölcsönzött dokumentum vonatkozásában blokkoltuk az előjegyzési lehetőséget.

Ezek után a megfelelő előkészitési ürlap kialakitása következett. Az átvétel helyének kiválasztása, az érdeklődés maximális dátumának megadása, illetve a helyszám (amennyiben a kérö az olvasóteremben tartózkodik) kitöltése után véglegesíthető (kérés küldése) az ürlap. Opcionálisan megjegyzési szöveg is csatolható a kéréshez. Az igénylés teljesitése egy-két munkanapot vesz igénybe (attól függően, hogy külső vagy belső raktári kérésröl van szó).

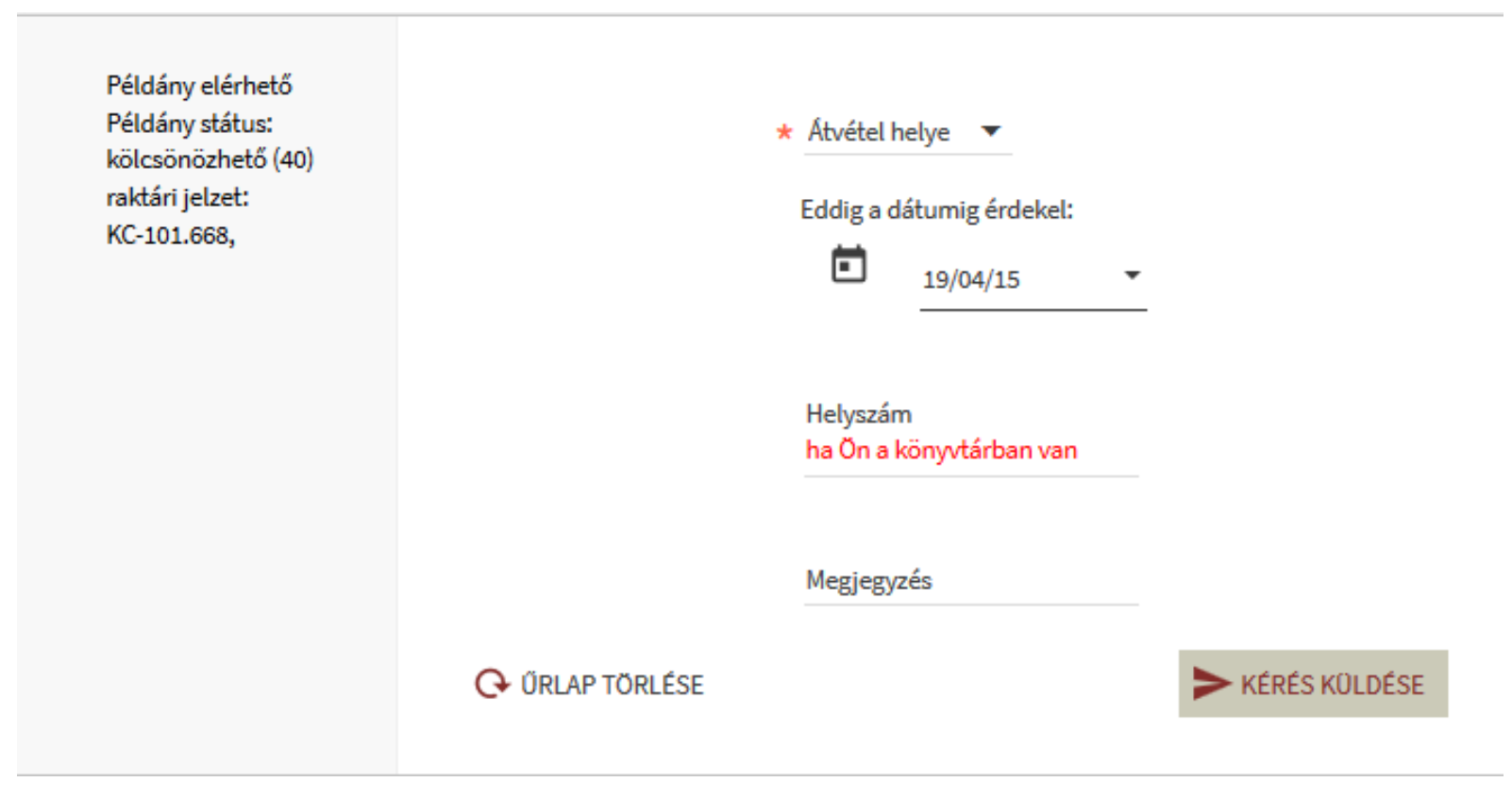

10. ábra Az előjegyzési ürlap a Primo-ban

\footnotetext{
10 A Primo a kölcsönzési - ezen belül az elöjegyzési - funkciók vonatkozásában a könyvtári rendszer (esetünkben az Aleph) beállitásait használja.

11 Ez a tab_hold_request tábla és a check_hold_request_w procedúra.
} 
Az olvasóknak szánt tájékoztató szövegeket egységesitettük, minden képernyőképen a „Raktári kérés” megnevezéssel jelöltük az előjegyzési funkciót. Abban az esetben, ha az adott müre nem lehet elöjegyzést tenni, igyekeztünk minél lényegre töröbben tájékoztatni a felhasználóinkat a továbblépés lehetőségéröl („Ez a dokumentum valószínüleg különgyüjteményben található. Forduljon a könyvtároshoz.").

\section{4. Összegzés}

A tesztelési időszak, valamint a közel fél éves éles müködés tapasztalatai alapján megállapitható, hogy az új verzió - elsősorban reszponzivitásából eredően - sokkal több lehetőséget rejt a felhasználóbarát felületek kialakitása terén. Fontosjellemzője az egyedi konfigurálhatóság, amely számos speciális szolgáltatás elinditását teszi lehetővé.

A rendszerben rejlö lehetőségek kiaknázása érdekében elengedhetetlen a dokumentáció áttekintése, a könyvtári rendszerrel való kapcsolatok feltérképezése.

Végezetül szeretném megköszönni Lovas Bálint informatikus kollégámnak a nyitóoldal kialakitásában végzett kitartó és ötletgazdag munkáját, valamint azokat az értékes információkat, amikkel segítette a tanulmány megírását. 